\title{
Asylum Provision and the East India Company in the Nineteenth Century
}

\author{
WALTRAUD ERNST*
}

Studies on the history of medicine and psychiatry in former British colonies have multiplied in recent years. ${ }^{1}$ The relevance of medicine and psychiatry in Britain to the development of colonial medicine and psychiatry within various Anglo-Saxon colonial settings has been firmly established. ${ }^{2}$ Yet the existence of any reverse impact is less certain. Although historians who specialize on developments in Britain have welcomed and favourably reviewed publications on colonial medicine and psychiatry, they do not on the whole engage to any great extent with the main themes of research in colonial medicine. Historians of colonial medicine and psychiatry therefore appear to be working in relation to, yet placed on the periphery of, mainstream Anglo-Saxon history of medicine and psychiatry.

Apart from the fact that research on the colonies is a relatively young discipline, there may be more compelling, if controversial, reasons for this. Historians of colonial medicine and psychiatry tend to focus on the European impact on the outside world and on how the colonial enterprise furthered the expansion of Western scientific knowledge. It is only recently, and largely due to the challenge of social science and literature-based theories of post-colonialism and subaltern studies, that this focus has been widened to look also at

Dr Waltraud Ernst, Department of History,

University of Southampton, Southampton.

The author would like to express her thanks to The Wellcome Trust for funding this project and to M Williams, B Harris, and the four anonymous referees for proof-reading and helpful comments. Many thanks also to the staff at the India Office Library and Records, the Hackney Archives Department, and the Ealing Local History Library.

1 For introductions to the history of colonial medicine see D Arnold (ed.), Imperial medicine and indigenous societies, Manchester University Press, 1988; R Macleod and M Lewis (eds), Disease, medicine and empire, London, Routledge, 1988; M Vaughan, Curing their ills: colonial power and African illness, Oxford, Polity Press, 1991;

D Arnold, Colonizing the body: state medicine and epidemic disease in nineteenth-century India, Berkeley, University of California Press, 1993; D Arnold (ed.), Warm climates and western medicine: the emergence of tropical medicine, 1500-1900, Amsterdam, Rodopi, 1996;
L Manderson, Sickness and the state: health and illness in colonial Malaya, 1870-1940, Cambridge University Press, 1996. See also, M Harrison, Public health in British India: Anglo-Indian preventive medicine, 1859-1914, Cambridge University Press, 1994. For histories of colonial psychiatry see W Ernst, Mad tales from the Raj: the treatment of the European insane in British India, 1800-1858, London, Routledge, 1991; M Lewis, Managing madness: psychiatry and society in Australia, 1788-1980, Canberra, AGPS Press, 1988; W H Williams, Out of mind. Out of sight: the story of Porirua Hospital, Porirua, Porirua Hospital, 1987; $M$ Finnane, Insanity and the insane in post-famine Ireland, London, Croom Helm, 1981; J McCulloch, Colonial psychiatry and 'the African mind',

Cambridge University Press, 1995; and H Deacon,

'Madness, race and moral treatment: Robben Island Lunatic Asylum, Cape Colony, 1846-1890', Hist. Psychiatry, 1996, 7 (2): 26.

2 See, Ernst, Mad tales, Lewis, Managing madness, Williams, Out of mind, Finnane, Insanity, note 1 above. 
indigenous responses and resistance to Western medical and psychiatric blueprints. ${ }^{3}$ What still awaits attention is the at times fatal impact of empire on a great number of largely lower-class people in Britain. The human cost of colonial service in socio-economic terms for the families of recruits; the impact on local social networks, Poor Law, relief and hospital services in Britain of colonial servants on their return; and, not least, the sociodemographic effects of a steady flow of diseased and invalided army, navy and civilian personnel back to Britain have yet to be investigated. ${ }^{4}$

My paper does not claim to fill the existing lacunae, but it is written with the above parameters in mind. Nor is it primarily concerned with the underlying anxieties or the political rationale that necessitated the removal from India of the European insane. ${ }^{5}$ Rather it focuses on the impact that the "empire" had, not only on indigenous peoples "out there", but also on the population in the metropolis itself. A study of institutions for those who-for whatever social or medical reason-failed to further the cause of empire, highlights one of the less salubrious consequences of colonial rule. The repatriation of deranged colonial servants to Britain literally brings home the fact that colonial rule also took its toll on the British.

This paper focuses on the two asylums used by the East India Company to provide for its mentally ill employees during the nineteenth century. The Company operated a number of lunatic asylums in India for those Europeans who became insane during service in the East. ${ }^{6}$ In addition, between 1818 and 1892, it made provision in England for private madhouses that specialized in the treatment of the Company's insane. Pembroke House, Hackney, indeed became the "largest, metropolitan establishment receiving private patients only". 7 The procedures involved in the hospitalization and treatment of the Company's insane and these private institutions' development in England will be documented and linked to the changes in the nature of colonial rule. The demographic, social and diagnostic profiles of patients will be discussed, and the colonial/overseas dimension of the history of the private mad-business in England will be addressed. ${ }^{8}$

3 Arnold, Imperial medicine, op. cit., note 1 above; $M$ Lyons, The colonial disease: a social history of sleeping sickness in Northern Zaire, 1900-40, Cambridge University Press, 1992.

4 This lack of literature contrasts with the wealth of the migration literature. Curtin, who recently focused on the "relocation cost" as a consequence of diseases acquired in the "tropics", discusses merely the financial dimension. P D Curtin, Death by migration: Europe's encounter with the tropical world in the nineteenth century, Cambridge University Press, 1989.

5 These have been described in W Ernst, 'The European insane in British India, 1800-1858: a casestudy in psychiatry and colonial rule', in Arnold, Imperial medicine, op. cit., note 1 above, pp. 27-44. For a discussion of the impact of active duty and war conditions see D M Peers, Between Mars and Mammon: colonial armies and the garrison state in India, 1819-1835, London, Tauris, 1995.

6 For European lunatic asylums in early nineteenth-century British India see W Ernst, 'Asylums in alien places', in W F Bynum, R Porter, and $\mathrm{M}$ Shepherd (eds), The anatomy of madness: essays in the history of psychiatry, vol. 3, The asylum and its psychiatry, London, Routledge, 1988, pp. 48-70. For lunatic asylums for Indians see W Ernst, "Native lunatic asylums" in early nineteenthcentury British India', in G J Meulenbeld and D Wujastyk (eds), Studies on Indian medical history, Groningen, Egbert Forsten, 1987, pp. 169-204.

7 W Ll Parry-Jones, The trade in lunacy: a study of private madhouses in England in the eighteenth and nineteenth centuries, London, Routledge and Kegan Paul, 1972, p. 43.

8 On the private mad-business see Parry-Jones, op. cit., note 7 above, and C MacKenzie, Psychiatry for the rich: a history of Ticehurst Private Asylum, 1792-1917, London, Routledge, 1992. See also, A Digby, Madness, morality, and medicine: a study of the York Retreat, 1796-1914, Cambridge University Press, 1985. For developments in nineteenth-century British psychiatry see the wide-ranging collections: W F Bynum, R Porter, and M Shepherd (eds), The anatomy of madness: essays in the history of psychiatry, vol. 1, People and ideas, vol. 2, 


\section{Waltraud Ernst}

The Company's lunatic asylums in England are an important part not only of the history of colonial psychiatry, but also of the history of psychiatry in Britain. However, the relevance of the Company's asylum data can ultimately be established in full only in combination with data on the other institutions which provided for colonial personnel hired by the British Army and the Royal Navy. Unfortunately, such comparative data are still lacking. The present study is therefore restricted to highlighting the potential relevance of British madness in the colonies for lunacy in Britain and to exploring how the East India Company data confirm or adjust existing accounts of the nineteenth-century private mad-business and official policies.

\section{The Private Mad-Business and Patronage by the Honourable East India Company}

In February 1819 Dr George Rees inserted an advertisement in the East India Register and Army List. ${ }^{9}$ Like many other medical practitioners he was trying to attract paying customers to his private mad-house. The "mad-business", as it had been termed, not without contempt, by those worried about abuses and unethical practices, was then highly competitive. ${ }^{10}$ Yet Dr Rees's establishment, Pembroke House, had something to offer which made it a cut above those of his competitors: it had not only received a "high encomium" from the select committee on the better regulation of mad-houses in England (1815/16), but had also been honoured by the distinguished patronage of the Honourable East India Company. As he emphasized in his advertisement, these two facts rendered it "unnecessary to say any thing more in [the asylum's] favor".

During the early nineteenth-century the ability to treat insanity promptly was still seen as an indication of a licensed house's high standard and efficiency. Rees therefore obligingly went on to elaborate-not unlike a tradition of advertisements which promised "No cure-no money"11 - that "the number is limited, the Patients are select, the advantages are considerable, and the terms reasonable", and that "three-fourths of those already admitted have been restored to health and reason". ${ }^{12}$ Dr Rees may have massaged his numbers a bit, as he omitted to mention that he had only recently, in August 1818, become the main contractor for the East India Company's mad employees in Englandhardly long enough to establish consistently high cure-rates. ${ }^{13}$ However, the promise of early cure was meant to reassure potential clients and their families and was, in fact, kept in a great number of cases during the subsequent two decades.

Institutions and society, vol. 3, The asylum and its psychiatry, London, Tavistock Publications, and Routledge, 1985, and 1988. G E Berrios and $\mathrm{H}$ Freeman (eds), 150 years of British psychiatry, 1841-1991, London, Gaskell, 1991; H Freeman and G E Berrios (eds), 150 years of British psychiatry, vol. II: The aftermath, London, Athlone Press, 1996; A Scull (ed.), Madhouses, mad-doctors, and madmen: the social history of psychiatry in the Victorian era, London, Athlone Press, 1981; and M Micale and R Porter (eds), Discovering the history of psychiatry, Oxford University Press, 1994.

9 India Office Library and Records (hereafter: IOR): East India register and army list, London,
Allen, February 1819, p. 497.

10 Parry-Jones, op. cit., note 7 above; MacKenzie, op. cit., note 8 above.

11 Advert in the Post Boy, 1700, for Clerkenwell Madhouse, London. Parry-Jones, op. cit., note 7 above, p. 102.

${ }^{12}$ East India register, op. cit., note 9 above.

13 Although Rees had occasionally received individuals formerly connected with the East India Company into his establishment before 1818 , the main intake of 18 patients did not arrive from India until 1819. IOR: Court Minutes, Reports and Resolution, 4.2.1820, 1114. 


\section{Asylum Provision and the East India Company}

The arrangement with the Company meant that those who experienced mental problems while in India would be transferred back to Rees's private mad-house in Hackney. Rees received the tidy sum of $£ 100$ per first-class and $£ 40$ per second-class patient, a charge which was competitive with other private lunatic asylums' fees. ${ }^{14}$ Despite such comparatively low rates, the arrangement was still lucrative. It also implied a considerable saving to the Company, as the cost of keeping European lunatics in asylums in the various provinces in India was much greater. ${ }^{15}$ What is more, medical opinion maintained that deranged Europeans would hardly ever recover when left in India, thereby threatening to become a permanent liability on the Company's accounts. The mere prospect of transfer back home was known to ease the mind of many a European lunatic, with symptoms sometimes disappearing as soon as a passage was procured. ${ }^{16}$ The Company would, of course, attempt to get patients' relatives to contribute to, if not take on the whole burden of, the expenses. In the case of soldiers and sailors this was, however, unlikely for reasons of economic distress. As regards lunatics of the higher social classes, the practice was to use the patients' accumulated salaries to defray at least part of the cost of maintenance at the asylum.

Rees was licensed to provide for 19 patients in his private establishment in $1819 .{ }^{17} \mathrm{He}$ received patients about once a year when the troop ships returning from India brought back invalided soldiers and those who had served out their term, as well as some of the lunatics who had not recovered in an asylum in India within a year. Rees therefore had no further need to advertise his establishment. The arrangement with the Company guaranteed him a steady flow of customers. The Company insisted on supervising the financial accounts as well as the institution's management and the medical treatment. It sent its own Examining Physician four times a year to check up on Rees and, from 1838, on Dr William Williams, Rees's successor. Dr Williams, too, had many years of experience in the running of small private houses for the insane, as he had been licensed to run three private mad-houses as early as $1822 .{ }^{18}$

Despite contemporary criticism, the concept of privately managed mad-houses fitted well with the ethos of the East India Company, which was, after all, anxious to fly the flag of free trade and mercantile enterprise. However, the Company could not count on keeping its mercantile monopoly in the East for ever (it lost it in 1813 for China, and in 1833 for India). Nor would the arrangement with Dr Rees, and later with Dr Williams, remain unopposed by the Lunacy Commissioners. ${ }^{19}$ When in 1852 Dr Williams asked for

14 For example, Bakewell's annual charge for paupers at Spring Vale was $\mathfrak{f 4 0}$. Parry-Jones, op. cit., note 7 above, p. 126. For further examples of maintenance charges see, idem, pp. 124-7.

15 Ernst, op. cit., note 1 above, pp. 61-3.

16 See, for example, the case described in W Ernst, 'Doctor-patient interaction in colonial India: a case of "intellectual insanity", Hist. Psychiatry, 1990, 1: 207-22. See also, the case of the "artichoke": as the patient's earlier mental symptoms "seem[ed] to have supervened" from the disappointment at not being sent to Europe after having suffered from sunstroke in the Persian Gulf, the doctor recommended his immediate transfer to England. Described in W Ernst and D Kantowsky,
'Mad tales from the Raj', Society, 1985, 22 (3): 31-8, p. 24. See also, the case of Gunner Michael D from Ireland who had a relapse when no passage could be procured for him: IOR: Records of Pembroke House and Ealing Lunatic Asylum (hereafter PELA), Medical Certificates, 1846, Registers of Admissions, 1845-61.

17 PP, 1819, xvII, Return of the number of houses licensed for the reception of lunatics.

$18 \mathrm{PP}, 1825$, XXI, Return of the number of houses licensed for the reception of lunatics.

19 Inspectorate provided by the Royal College of Physicians; from 1828 the "Metropolitan Commissioners"; and from 1845 the "Commissioners in Lunacy". On the context for the Lunacy 


\section{Waltraud Ernst}

permission to extend the by then overcrowded premises of Pembroke House, the Commissioners saw their chance to get the Company to move its insane employees to public institutions, avoiding the private mad-business. They suggested that the Company's military employees should be transferred to the Royal Military Lunatic Asylum at Great Yarmouth, and that former sailors should be sent to the Royal Naval Hospital at Haslar. ${ }^{20}$ At the time, opposition to private mad-houses was at its height. ${ }^{21}$ The Company was not, however, in favour of sending its former employees to these more costly public institutions, objecting to the fact that they were also frequented by a large number of pauper inmates. As the Company's Board of Directors was alert both to potential financial savings and to social class (and, within the colonial context, racially appropriate provision), lunatics returning from India continued to be sent to Pembroke House.

It may appear surprising that the Company, usually keen to bring its affairs into line with policies in Britain, declined to withdraw its patronage from the private trade in lunacy. However, in this it merely mirrored the British government's own contradictory and highly criticized stance. For example, in 1854, the government decided to transfer some lunatics, who had previously been confined at the Royal Military Lunatic Asylum, to a private licensed house. ${ }^{22}$ Parry-Jones points out that this measure "seems paradoxical in view of the official attitude towards licensed houses", and that it "aroused much strong feeling". ${ }^{23}$ The issues at stake were highlighted by an editorial in the Asylum Journal in 1855 entitled 'The want of a military lunatic asylum' ${ }^{24}$ It was argued that while "the Legislature has been emptying licensed houses, Government has been filling them". 25 Although the private licensed house involved (Grove Hall) was reported to have "deserved and enjoyed the marked favour of the Commissioners in Lunacy" 26 as far as management and medical care were concerned, it was the violation of the principle of "removing the insane poor from the custody of the speculators" which was considered objectionable. ${ }^{27}$ The Government's own contradictory measures (which were related to the pragmatic consideration that it was cheaper to "farm out their insane dependants to the keepers of those licensed houses which are now closed [to counties and boroughs] by the operation of Acts of Parliament") fitted in with the Company's partiality for low costs and private enterprise. ${ }^{28}$

However, in 1870 the Commissioners in Lunacy saw another opportunity to suggest to the Company a contract with a public asylum, when the Great Eastern Railway Company demanded possession of the buildings in Hackney for further property development. ${ }^{29}$ In

Commissioners' opposition to private mad-houses see N Hervey, 'A slavish bowing down: the Lunacy Commission and the psychiatric profession 1845-60', in Bynum, Porter, and Shepherd, op. cit., note 8 above, vol. 2, pp. 98-131; D J Mellett, 'Bureaucracy and mental illness: the Commissioners in Lunacy, 1845-90', Med. Hist., 1981, 25: 221-50.

${ }^{20}$ In 1846 the Royal Naval Hospital at Great Yarmouth was converted for the reception of military lunatics, and renamed Royal Military Lunatic Asylum. In 1854 it became again a hospital for sailors. From 1818 part of the Naval Hospital at Haslar had been set aside for insane officers and seamen.

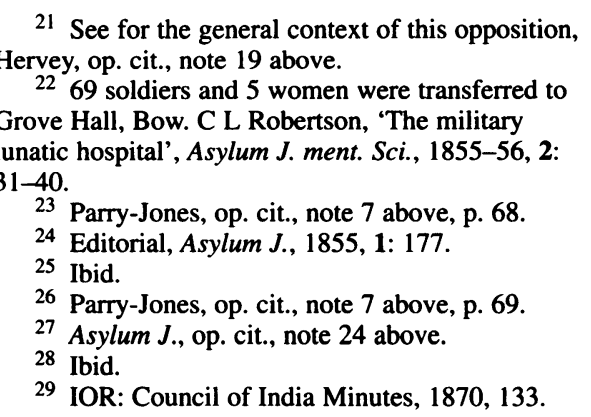


line with tradition, Dr Williams proposed that the patients and staff be assigned to yet another renowned private mad-house proprietor, Dr J H Paul of Camberwell House. Predictably, the Commissioners objected, because "all the achievements of private madhouses and the contributions which resulted from the enterprise of private individuals could not outweigh the real and fancied defects of a system based on the principle of profit". ${ }^{30}$ The War Office was therefore approached with a view to removing the patients from Pembroke House to the new asylum at Netley. ${ }^{31}$ Instead, it offered its old, deteriorating buildings at Chatham (used for military lunatics since 1819), to which the Commissioners strongly objected. Thus, once again, the fall-back position of a private establishment was considered, or rather "pushed through as quietly and expeditiously as possible" in order to pre-empt public criticism and yet another adverse response by the Commissioners. ${ }^{32}$ Dr Thomas Beath Christie, who had for a time worked at Pembroke House, together with the architect Sir Mathew Digby Wyatt "carefully inspected" a property which was then up for sale: the Elm Grove Estate, a private manor house in Ealing. The India Office decided to purchase it. After some conversion, the new asylum, named the "Royal India Asylum Establishment", was opened in 1870. Despite continued pressure by the Commissioners, it remained the principal receptacle in England for former Company employees until 1892.

Although by 1872 the view was expressed by the India Office that the Royal India Asylum at Ealing would "become unnecessary shortly", because of the disbandment of the Company's military services, a small yet continuous trickle of former Company servants, getting older on admission and more frequently belonging to the higher classes, ended up in Ealing until $1892 .{ }^{33}$ In that year, finally, the remaining 76 patients were referred on to various public establishments such as the Royal Naval Hospital at Yarmouth and the Coton Hill Institution, Stafford.

The history of Pembroke House and of the Royal India Asylum at Ealing spans nearly the whole of the nineteenth century. To some extent it mirrors the history of the East India Company during this period: the lingering heyday of private enterprise, succeeded by ambivalence towards public institutions around the middle of the century, and by ultimate submission to government control and public influence. It also shows that the Company's Directors were little affected by sensational reports about abuses of inmates by private mad-house owners more interested in making a profit than in bestowing an appropriate level of care and consideration on their insane charges. After all, the Company itself had grown strong in the pursuit of profit and was therefore not hostile to private enterprise per se-especially when private services worked out cheaper. The Directors were also confident that the Company was able to exert a level of control over the private mad-house owner which would prevent the occurrence of any potentially headline-grabbing abuses of patients.

\footnotetext{
30 Parry-Jones, op. cit., note 7 above, p. 291. For a discussion of the Lunacy Commission's failure to work out a consistent policy see Hervey, op. cit., note 19 above, esp. p. 113. Camberwell House was the last of the huge London pauper licensed houses to receive its licence in 1846.

31 'Royal Victoria Hospital, Netley', Br. med. J., 1966, i: 412-13.
}

32 IOR: PELA, Registers of Admission, 1878, Memorandum on the history of Pembroke House and Ealing Lunatic Asylum.

${ }_{33}$ PP, 1872, viII, Select Committee on East India Financy, Minutes of Evidence, 327, pp. 3-5. 


\section{Asylums in India}

The rationale for the maintenance of a Company lunatic asylum in Britain arose directly from necessities in British India. From the late eighteenth century instances of Europeans going mad in India had been reported. These were dealt with initially by friends or by individual Company doctors who agreed to look after such persons temporarily. With time and the continued expansion of Company influence and rule, the number of cases increased so that Company doctors in the various provinces began to introduce the "trade in lunacy" to India. The principle of valuing medical practice for its prospect of lucrative side-lines was nothing out of the ordinary-either in Britain or in the setting of the Company. The fame of great fortunes to be made in the East lingered on long after the real opportunities to do so were past. Following the battle of Plassey, the Company's involvement in India shifted, according to Kiernan, from "mere collection of loot . . to orderly, if still burdensome administration". 34

Although it is difficult to ascertain whether the promise of Eastern riches was a main motive for medical doctors' decision to work in India, many a large fortune was indeed made there. The residency surgeon at Lucknow, for example, would, in 1785, earn as much as Rs 8,000 per month, mainly through allowances from one of the princely houses. Further, as Company surgeons also held military commissions, they would be issued prize money. For example, after the "battle of Bijaigarh", surgeons and assistant surgeons received Rs 22,478 and Rs 11,239 respectively. ${ }^{35}$ Even as late as 1836 the India Journal of Medical and Physical Science related the story that in "Lord Lake's camp such were the enormous receipts in consequence of [hospital] contracts for supplying corps with medicine, diet, and dhoolees [litter bins], that Doctors Monroe and Cockrane especially realised the largest fortunes ever made in this country". ${ }^{36}$

In Madras, Dr Valentine Conolly gained fortune as well as fame as the owner of the local asylum. Similarly in Calcutta, Dr Dick owned the local lunatic asylum and was considered an influential member of the town's Eurasian community. Increasingly, however, extravagance, large private profit, and waste of public monies were being noted. The Company was also subject to the examination of a governmental Board of Control which kept an attentive eye on the enforcement of efficient administration and frugal finances. Every twenty years the Company had to undergo extensive scrutiny by Parliament prior to the renewal of its charter (in 1813, 1833 and 1853). Humanitarian reformers, too, concerned themselves with the welfare of the Company's European employees as well as that of its Indian servants, if not by touring British India, then at least by studying the Company's reports. Campaigners such as Sir Andrew Halliday, for example, took great pains to check the Company's reports on its management of lunatics-although his judgement in 1827 was that it was "much further advanced" than the system of care current in British lunatic asylums. ${ }^{37}$

34 V G Kiernan, The lords of human kind: European attitudes to the outside world in the imperial age, Harmondsworth, Penguin, 1972, p. 37.

35 D MacDonald, Surgeons twoe and a barber: being some account of the life and work of the Indian Medical Service, 1600-1947, London, Heinemann, 1950, pp. 86-7.

\section{Ibid., p. 86.}

37 A Halliday, A general view of the present state of lunatics, and lunatic asylums, in Great Britain and Ireland, and in some other kingdoms, London, Underwood, 1828, p. 65. 
Financial economy was an important consideration and, as the rates of maintenance in asylums in India proved to be consistently higher than in Britain, transfer of Europeans back to Britain was considered vital. Of course, there were other reasons, too. Although mental illness was at the time considered to be curable in most cases, there was always a small number of patients who would not recover and who needed permanent care. As most Europeans in British India during that early period would not have had any family connections locally, it was seen as necessary to send these "friendless" lunatics back home. There was always a chance that relatives in Britain would take care of them privately or at least contribute towards their upkeep in an institution.

There was also an assumption, widely held among European doctors and the European public in British India, that the East was a difficult enough place for healthy Europeans, let alone for those of a delicate constitution or a deranged mind. As well as having a hostile climate and adverse environmental conditions, the plains of India were seen as full of temptations such as alcohol and other vices. ${ }^{38}$ Only a few "experimental sanatoria" that provided for convalescent British soldiers had been established by the early 1830 s, and hill-stations were not yet opened up for general recreational and health pursuits during the first half of the nineteenth century. ${ }^{39}$ The best chance of recovery for disturbed European minds was therefore repatriation. The superintendent of the lunatic asylum at Bombay expressed in 1852 the commonly-held view that although "it affords good ground . . for a recommendation that [a patient] should not return to duty, [it] must be admitted, that in no instance, after an attack of insanity should a man be permitted to remain in circumstances and relations which are obviously so likely to lead to a relapse". 40

The delicate subject of the impact that mentally deranged Company servants might have on the "natives" also played a part in the decision to deport mad Europeans. Indian lives would, of course, not be endangered if the mad were contained within lunatic asylums in India. But what about the British reputation? What of British superiority of morals and intellect? The assumed prestige of the British was a vital facet of colonial ideology, and it was feared that the "European Character" would be lowered in the "eyes of the Natives" if lower-class Europeans or lunatics were allowed to roam about freely, or were known to be present for extended periods within institutions in India. ${ }^{41}$ As a consequence of this concern with keeping up appearances, various measures were

38 On the well-grounded fears of Company officials and medical practitioners that young recruits as well as "old India hands" would succumb to alcoholism and venereal diseases see $\mathrm{K}$ Ballhatchet, Race, sex and class under the Raj: imperial attitudes and policies and their critics, 1793-1905, London, Weidenfeld and Nicolson, 1980. For contemporary accounts see also, J M'Cosh, Medical advice to the Indian stranger, London, W H Allen \& Co, 1841.

39 The possibility of a lunatic hill-station had been investigated in 1827 and, again, in the late 1840s. IOR: Bengal Military Proceedings, 12.4.1827, 208. Bengal Public Despatch, 5.2.1851, 18. The idea was however abandoned in each case. It was argued that "The climate of the hills might be more congenial to European Patients, but the majority of these would doubtless be soldiers, who, when once attacked with insanity, were rarely afterwards fit for the duties and excitements of Military Life in India". IOR: India Public Works Despatch, 20.8.1856, 16. For a more detailed discussion see W Ernst, 'Psychiatry and colonialism: the treatment of European lunatics in British India, 1800-58', London, University of London (SOAS) PhD thesis, 1986, pp. 54-7.

40 IOR: PELA, Medical Certificates, 1852, Case of $\mathrm{H} \mathrm{S}$.

41 IOR: Resident at Indore to Government of India, 31.10.1838. India Political Proceedings, 14.5.1838, 182. See also Ballhatchet, op. cit., note 38 above. 


\section{Waltraud Ernst}

implemented to preserve the prestige of the ruling elite. ${ }^{42}$ The presence of European adventurers and loafers, as well as lunatic vagrants, in India was disapproved of and was dealt with by means of what Victorians considered "relief" measures (namely imprisonment, establishment of work-houses, and deportation). ${ }^{43}$ Likewise, the deportation of lunatics was considered a great relief-not least for the European middleclass community in British India. At a time when talk of white rational superiority was growing, irrational behaviour carried the added threat of tarnishing cherished colonial myths. Although confinement in local institutions would have kept European lunatics out of sight (even if still within earshot of nearby Indian communities), such establishments were predicted to grow and thus have the potential to become more visible. Even the 1827 suggestion of building a lunatic hill-station was still considered as giving too high a profile to a problem which could be resolved more satisfactorily by deportation. ${ }^{44}$ European asylums in British India were therefore destined to remain small-scale establishments, providing only for the temporary custody of European lunatics awaiting embarkation to Britain..$^{45}$

\section{A Passage from India}

How then, once it had been agreed to deport a lunatic from India, was a typical passage to be managed? Take the example of the Agamemnon, which left for Europe at the beginning of the hot season in South India, in April 1821. On board was Major G R G who had arrived in India in October 1795 on the Earl Fitzwilliam to begin what he expected to be a prosperous career in the East. ${ }^{46}$ Subsequently, he indeed "passed through the different ranks of the army", being described as a "fair character". However, following an expedition to the Isle of France in 1810, he began to believe that he was Lord Nelson, and to indulge in what were described as "Bacchanalian excesses". As might be expected, he was considered insane and admitted to the Lunatic Asylum at Madras (Chennai). ${ }^{47}$ This establishment was then run by Surgeon J Dalton, who was known to have made a small fortune through various hospital contracts and the asylum. ${ }^{48}$ The asylum then provided for about thirty patients of various social and racial backgrounds. Separation between the races and the social classes of inmates was however maintained. Major $\mathbf{G} R \mathbf{G}$ was admitted as a first-class patient. He benefited from superior quarters, generous meals and various gentlemanly recreational pursuits such as reading, smoking, drinking, and card

42 White colonization of India was generally objected to, not only because of fear of lower-class settlers spoiling the favourite career playground and the prestige of the aspiring British "middle-class aristocracy" in India, but this was a main consideration. For a discussion of the various other factors involved see D Arnold, 'White colonization and labour in nineteenth-century India', J. imp. commonw. Hist., 1983, 2: 133-58.

43 On Victorian relief measures see D Fraser, The evolution of the British welfare state: a history of social policy since the Industrial Revolution, London, Macmillan, 1984. A Digby, The Poor Law in nineteenth-century England and Wales, London, Historical Association, 1982.
44 IOR: Bengal Military Proceedings, 12.4.1827, 208. Bengal Military Letter, 14.10.1830, 156. Bengal Military Despatch, 12.12.1832, 7.

45 For the motives underlying the establishment by the Company of lunatic asylums for Indians see Ernst, op. cit., note 6 above.

46 For data on Agamemnon patients refer to: IOR: Proceedings for sending European insanes to England, Madras Military Letter, 3.4.1821, 23, and Madras Military Despatch, 22.9.1822, 18485.

47 For details on the asylum see Ernst, op. cit., note 1 above, pp. 61-86.

48 For details on the lucrative Madras madbusiness see Ernst, op. cit., note 39 above, pp. 149-52. 


\section{Asylum Provision and the East India Company}

games. It is not known whether the daily breakfast of "the first Sort", including sugar, tea, butter and fried saltfish, as well as a dinner (on Mondays) of one pound of roasted mutton, broth, bread and vegetables, met with his approval. It is however clear that he and the other first-class patients enjoyed a measure of luxury.

When it was recommended in 1820 that he be repatriated to England, Major G R "Nelson" G was embarked on the Agamemnon together with several other first and second-class patients. Among them was Mr W P (formerly a surgeon and captain in the service of His Highness the Nizam of Hyderabad), whose behaviour was considered "extremely eccentric", even if his "chequered life" was taken into account. (Mr W P had "successively acted in a Medical and Military capacity as also in that of a Player at the Theatre of Madras".) There were also Captain J H (who had suffered a ship-wreck and subsequently become insane) and Mrs E M S (widow of a former Colonel S), whose insanity was described as being of a "very outrageous nature".

In preparation for these lunatics' repatriation, much attention was paid to the inventories for the first-class passengers. Clearly they did not travel light, nor wish to take leave of personal articles. For example, the baggage of Colonel S's widow included 234 white shirts, 156 trousers, 16 white pocket handkerchiefs, 36 chintz petticoats, 78 pairs of men's shoes, 12 pairs of women's shoes, as well as 6 straitjackets, 80 lbs of country soap and 3 foot tubs, 4 tables, 4 chairs, and 13 straw hats. First-class decorum and procedures were observed as a matter of course during the three to four month voyage. A special female attendant and a servant were engaged exclusively to look after the Colonel's widow. The procedure for second-class patients was, of course, less elaborate. Their passage, after all, cost the Company only Rs 500 each, whilst ladies, gentlemen and officers could be got under sail for no less than Rs 2,000 to Rs 3,000.

The group of fifteen patients was to be accompanied by ten attendants (mainly meant to wait on the first-class patients) and by a surgeon, who was allowed to draw a higher allowance than would have been usual for ships' surgeons on account of the "very peculiar character of the Medical Charge entrusted" to him. The fact that the repatriation of lunatics was a somewhat "peculiar" process was brought home to the marine authorities too, as they found it difficult to procure passages for insane people. It was argued that the "comfort and safety" of other passengers was "greatly endangered by having insane Patients on board" and, in fact, influential travellers, such as Lady Grey, would not agree to travel on the same vessel as their deranged compatriots. ${ }^{49}$

Over the years, the procedure of procuring a passage for lunatics would of course become routine and less haphazard. From the 1830s onwards the European insane were sent on troopships together with invalids and time-expired soldiers, thereby preventing delays on account of other passengers' complaints or the refusal of ships' captains to take what they considered an inconvenient cargo of irritating "fools" or dangerous maniacs. 50 Savings could also be made on account of surgeons being available on troopships at noor a trifling —extra charge, and attendants and servants were more easily recruited from amongst invalids and soldiers for minor allowances. The principle of shipping lunatics back to Europe once a year prevailed throughout the century, with Bombay becoming the favoured embarkation port. This procedure soon became so well established among

49 IOR: Bengal Commercial Despatch,

50 IOR: Bengal Military Despatch, 1830. 13.3.1833. 


\section{Waltraud Ernst}

government authorities and medical practitioners that they aimed at transferring their mentally deranged patients from far-away out-stations just in time for embarkation so that the period of temporary confinement in one of the three European lunatic asylums (in Calcutta, Bombay (Mumbai), and Madras) could be brief.

Not much is known about the lunatics' life on board apart from occasional reports of the insane frightening other passengers and of soldiers taking turns in teasing them. Like everybody else on board ship during those decades, the insane suffered from scurvy and other symptoms of malnutrition-at least those on the lower decks who were not considered suitable company to dine occasionally at the Captain's table. Despite the fact that some lunatics died during their passage from India, most arrived at the docks in England not much worse for wear than the other passengers. However, once in England, problems began to emerge. Ships' estimated arrival times were not always precise. Vessels might berth days early or weeks late. At times, quarantine procedures complicated the hand-over of lunatics to asylum attendants. In the general turmoil on arrival, lunatics might wander off or abscond. At times this worked to the advantage of the Company in financial terms, as the cost of institutional confinement at Pembroke House literally disappeared down the back-alleys. However, frequently the police would catch up with free roaming lunatics and duly pass them on to India House. The mad-house proprietors had, of course, a vested interest in taking care of as many patients as possible, so there existed an incentive to struggle to get a carriage to the ship on time. Unlike the situation in British India, where administrative procedures were meticulously organized by the Company's bureaucracy, things did not always run so smoothly in England. Diverse agents and agencies with different interests and priorities, such as the ship's captain, the marine authorities, the ship's surgeon, the Company's administrators, and the private madhouse owner, as well as the carriage driver and the attendants, had all to cooperate.

\section{Pembroke House Lunatic Asylum}

If the mentally ill passengers survived the voyage, and the picking-up procedures were implemented correctly, patients would arrive within a couple of days at the latest at the Company's lunatic asylum: Pembroke House (from 1818) or The Royal India Asylum (from 1870 until 1892). Pembroke House was located at Mare Street, in Hackney, close to what is nowadays Bayford Street. ${ }^{51}$ It was described as a "large lunatic asylum . . . with beautiful grounds", and photographs show that it was an imposing building. ${ }^{52}$ Despite its later spaciousness, in its early days the place was small-scale, in common with most private lunatic asylums during the early decades of the nineteenth century. When Dr Rees gained the East India Company's patronage in 1819, he was licensed to receive only 10 male and 9 female patients. Numbers would, of course, increase with the years. In 1838, when Dr Williams took over as superintendent, there were 75 male and 5 female patients. In 1846 a total of 99 patients were accommodated, distributed almost equally between first-class apartments (48 patients) and second-class wards (51 patients).

51 Hackney Archives: I Watson, Hackney and Stoke Newington past, Herts., Historical Publications, 1990 , p. 58.

52 Hackney Archives: B Clarke, Glimpses of ancient Hackney and Stoke Newington, London, London Borough of Hackney and the Hackney Society, 1894 (edited with a new Introduction by D Mander, 1986), p. 15. 


\section{Asylum Provision and the East India Company}

The grounds in which Pembroke House was set were spacious enough to allow for extensions to provide for a five-fold increase in the number of inmates over a period of about three decades. Although Dr Rees made an effort to promote his establishment as one that would satisfy the superior demands of people of the better sort, there are indications that, by the middle of the century at the latest, upper-class people preferred to have their loved ones sent to more exclusive institutions (Ticehurst Asylum, for example, described as "the Mecca of private asylums" by 1900). ${ }^{53}$

The fees charged by Dr Rees during his superintendence from 1818 to 1838 compare well with those of other private asylums in England. ${ }^{54}$ The more drastic change occurred towards the latter part of the nineteenth century. In 1871, for example, the cost of a firstclass (male) patient was estimated at $£ 85$ per annum, while for a second-class patient $£ 45$ was deemed to cover most expenses. The charges had thus been reduced in the case of first-class patients and in the case of second-class inmates hardly kept pace with the rate of inflation. This tendency towards lower charges and, consequently, deteriorating conditions was not unique to the Company's asylums, but was fairly typical of developments in asylums at this time. ${ }^{55}$ However, the Company was less successful in achieving drastic cuts in expenses in England than it was in India. The fact that the Company's affairs in England were more directly subject to the Victorian public's attention than those in far-away British India may have been a major factor. ${ }^{56}$

\section{The Royal India Lunatic Asylum}

Apart from its financial aspects and geographical location, we know more about the Royal India Asylum at Ealing than we do about Pembroke House. This is partly because, unlike Pembroke House, the buildings at Ealing were actively sought out and purchased by the India Office after failed attempts to transfer the Company's lunatics to already existing special institutions such as Fort Pitt, Chatham. ${ }^{57}$ When the Elm Grove Estate at Ealing came up for sale, Sir Mathew Digby Wyatt, the Company's trusted architect, together with Dr Thomas B Christie, were sent to inspect the place. ${ }^{58}$ (Christie, who had gained the Company's confidence while previously engaged in the temporary superintendence of Pembroke, was appointed Superintendent of the Royal India Asylum in 1870, and was to become one of Ealing's "widely known and respected" gentlemen.) The buildings at Ealing were then owned by the Perceval family who had their own peculiar connection with the insane: Spencer Perceval, the Prime Minister of England, was assassinated in 1812 by an alleged lunatic. His son, J T Perceval, was himself believed to suffer from madness, and had been a patient at Brislington House (1831-32)

53 Parry-Jones, op. cit., note 7 above, p. 119. See also, C MacKenzie, 'Social factors in the admission, discharge, and continuing stay of patients at Ticehurst Asylum, 1845-1917', in Bynum, Porter, and Shepherd, op. cit., note 8 above, vol. 2, pp. 147-74.

54 See, for charges, note 14 above.

55 A Scull, The most solitary of afflictions: madness and society in Britain, 1700-1900, New Haven, Yale University Press, 1993.
56 Clarke, op. cit., note 52 above, p. 15. When at last the Great Eastern Railway took over Pembroke House for its own purposes in 1870 some of the area previously surrounding it was developed to bear, in the words of a local historian, "unmistakable evidence of self-appropriation of what was once common land".

57 IOR: Council of India Minutes, 1870, 133.

58 Ealing Local History Library: E Jackson, Annals of Ealing, Phillimore, 1898, p. 203. 


\section{Waltraud Ernst}

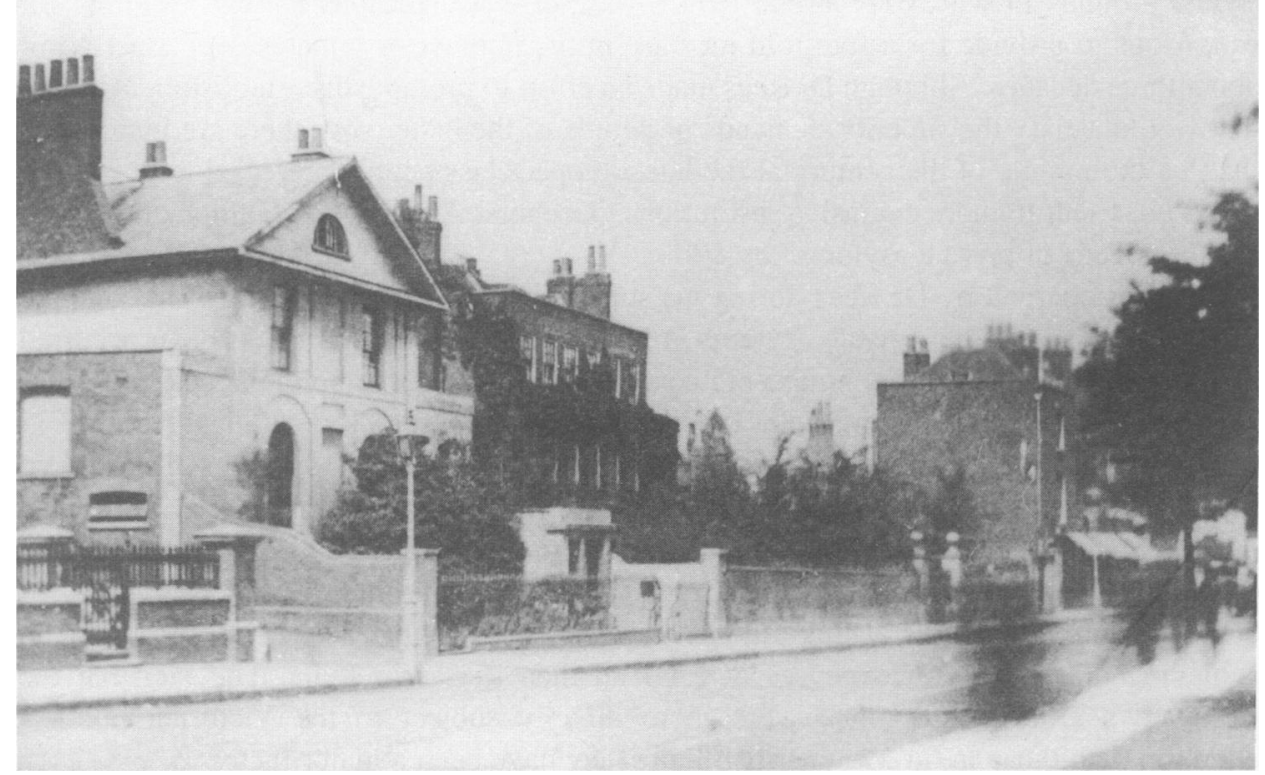

Figure 1: Pembroke House Lunatic Asylum, Mare Street, Hackney, c. 1871. The Asylum is set back from the street with the surgeon's house on the left and a row of shops on the right. (Photograph by George James, reproduced by permission of Hackney Archives Department.)

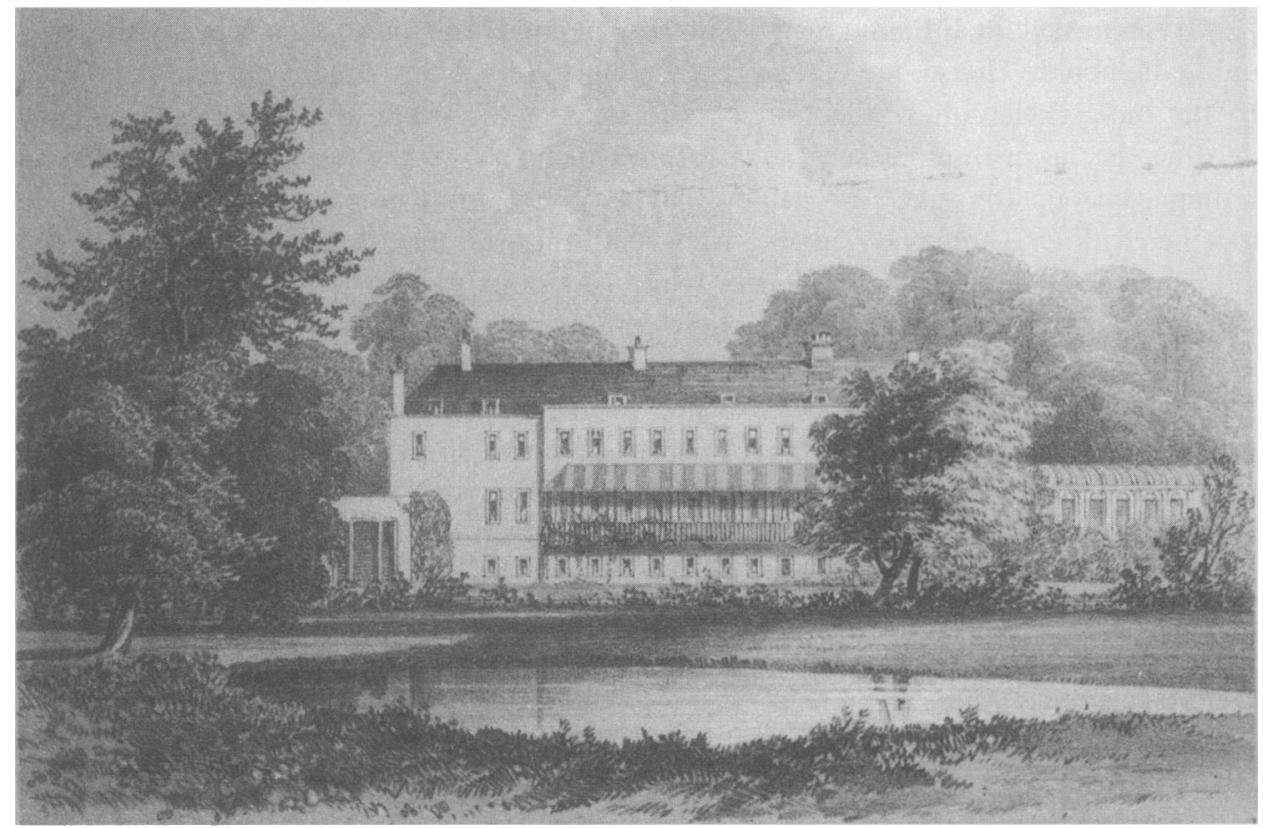

Figure 2: Elm Grove in 1870 when it was bought by the India Office to be turned into the Royal India Lunatic Asylum. From a drawing by T M Elton. (Ealing Public Libraries, Local Collection, reproduced with permission.) 
and Ticehurst Asylum (1832-34) ${ }^{59} \mathrm{He}$ had also helped to form the Alleged Lunatics' Friend Society in $1845 . .^{60}$ The Perceval family may well, as a result, have had some interest in having lunatics locked up securely, as well as in style. It is not known whether the family history influenced the decision to sell Elm Grove to the India Office with a view to housing lunatics. However, it is clear that the estate's proprietor in 1870 (one Anna Elizabeth Perceval) realized some considerable profit from the sale of the estate for $£ 24,500$. The late Prime Minister had bought it from Lord Kinnaird in 1808 for $£ 7,000$ for the property and $£ 5,000$ for the timber. Some $£ 12,000$ was spent by the Company on converting the formidable former residence into an asylum. Following the redesign under the direction of Wyatt, the "large, plain, stuccoed building of three storeys and attics"61 was considered to be a "well-built house, large enough to merit the term mansion, plain in design, but not without architectural beauty, and with walled grounds surrounding it". ${ }^{62}$

The imposing building, described in 1845 as a "commodious family residence of a plain but desirable character", was set in an estate of about thirty-eight acres and lived up to the standards of seclusion, exquisite surroundings and inviting aesthetics promulgated by the Tukes in the Retreat at York. ${ }^{63}$ At that time it was still relatively detached from the village of Ealing, being situated on the edge of the Common. Above all, the location was "healthy". ${ }^{64}$ Indeed, Perceval had originally purchased Elm Grove because of the salubrious effect it was expected to have on the health of his wife. ${ }^{65}$

Pembroke House's patients were moved to their new abode at Ealing in August 1870. Although the newly converted institution could accommodate up to 156 patients (110 purpose-built second-class facilities, 23 suites for first-class patients, and a further 23 places for female patients), it was not to reach full capacity. It was agreed that "the vacant beds should be filled from cases that are chargeable to the Indian Government", and which

59 G Bateson (ed.), Perceval's narrative, Palo Alto, Stanford University Press, 1961. R Hunter and I MacAlpine, 'John Thomas Perceval (1830-1876): patient and reformer' (review of Perceval's narrative), Med. Hist., 1962, 6: 391-5. See also, MacKenzie, op. cit., note 8 above.

60 N Hervey, 'Advocacy or folly: the Alleged Lunatics' Friend Society, 1845-63', Med. Hist., 1986, 30: 245-75.

61 Ealing Local History Library: Victoria County History, vol. 7 (Middlesex), p. 130.

62 Jackson, op. cit., note 58 above, p. 202.

63 Ealing Local History Library: T Faulkner, History and antiquities of Brentford, Ealing and Chiswick, Peyne and Foss, 1845, p. 242. For information on the Retreat at York see A Digby, 'Moral treatment at the Retreat, 1796-1846', in Bynum, Porter, and Shepherd, op. cit., vol. 2., note 8 above, pp. 52-72, and idem, op. cit, note 8 above; and idem, 'Changes in the asylum: the case of York, 1777-1815', Econ. Hist. Rev., 1983, 36: 218-39.

64 Jackson, op. cit., note 58 above, p. 204.

65 Elm Grove (before 1808 known as Hiches atte hethe or Hickes-upon-the-Heath) had gained its name from a "triple line of elms, some 300 to 400 yards in length" which ran alongside the estate, and the reputation of the beauty of the many fine trees in the pleasure grounds. Its 26 acres of meadow and pasture and 10 acres of laid out gardens, with a broad walk edged with thick shrubbery leading around the premises, attracted the enthusiastic attention of the local Horticultural Society which even held its shows in the grounds from 1864 onwards. Several members of the Horticultural Society objected to keeping Elm Grove as the venue for its annual shows once the place had been converted to an asylum indicating that a certain stigma was attached to lunatics. Dr Christie, however, worked hard at increasing the profile of the Royal India Asylum as an exquisite institution. He showed interest in the Society and also soon gained some local reputation (as first Ruling Councillor of the Ealing Habitation of the Primrose League, as a member of the Ealing Constitutional and Conservative Clubs and as a pious man who attended in Perivale Church not once but twice every Sunday). Jackson, op. cit., note 58 above, p. 205. Ealing Public Libraries, Local Collection-Elm Grove, EEB 15.8 Elm Copy 3, 1962, n.p. 


\section{Waltraud Ernst}

had for various reasons ended up in other asylums. ${ }^{66}$ The number of patients averaged around 110, most of whom were described as paralysed and helpless. These were mainly people who suffered from what was seen to be chronic mental illness, some of whom had been admitted during the early years of Pembroke House.

The question of whether the India Office was also responsible for pauper lunatics seems to have been the subject of some controversy. In 1870 the India Office had tried to transfer a pauper lunatic to the Middlesex County Asylum to be provided and paid for by the Hackney Union. The Hackney Union, however, rightly suspected that if it received one pauper "Indian lunatic" this might be "construed into an admission on the part of the Guardians, of a legal liability to maintain the whole of them". This the Union was careful to "entirely repudiate". ${ }^{67}$ Local unions in general struggled during this period to get rid of as many paupers as possible in order to avoid having to provide financial assistance for them.

Compared to conditions at public asylums during the second half of the nineteenth century, those at the Royal India stood up favourably, not least because of the relatively high staff to patient ratio of about 1 to 5 (if calculated on the number of both second and first-class patients). Even if staff were more freely allocated to patients of the first class, the ratio remains favourable. For an average of about 110 patients during the 1870 s, 22 (23 from 1875) servants and 5 officers (including a Chaplain) were employed. ${ }^{68}$

Those involved with the administration of the Royal India Asylum anticipated at the time of its inauguration that it would "become unnecessary shortly" and that it would "at no remote period" be "broken up". This reasoning was based on the assumption that along with the dispersal of the Company's army and its withdrawal from civil administration in India in 1858, mad Company servants and affiliates, too, would simply disappear. The assumption proved correct insofar as few new referrals to the Asylum were made from the 1870s. This was offset, however, by the tendency for the long-term mentally ill to accumulate there. It took a further two decades for the India Office to realize that the average number of occupants at Ealing was to remain pretty stable, with long-term patients dying only slowly. There was no great incentive to maintain such an establishment, especially after the 1890 Lunacy Act (53 Vict., c. 5), which forbade the issue of new licences and expansion of existing ones, and at a time when properties and land in Ealing were at a premium. When Dr Christie died in 1892, therefore, the India Office took the opportunity to have the remaining insane moved into other institutions.

The male patients were sent to the Royal Naval Hospital at Yarmouth, and the female patients went to the Coton Hill Institution, Stafford. The India Office had to defray from the revenues of India $£ 100$ per year for first-class female patients, and $£ 1$ a week for the

66 Such as Brentwood, Maidstone, Colney Hatch, Hanwell, Liverpool. See IOR: PELA, Medical Certificates, 1867-70, Letter from India House to Pembroke House, 6.8.1868.

67 IOR: PELA, Medical Certificates, 1867-70, Letter from Hackney Union to Pembroke House, 17.2.1870, Case of Owen H. The India Office restricted admission to the Royal India Asylum to those who had been in the Company's military services. This decision was made possible in consequence of the Union Chargeability Act of 1865 ( 28 \& 29 Vic. c. 79 ) which provided for paupers to be referred to the care of their local Board of Guardians.

${ }^{68}$ IOR: PELA, Memorandum on the history of Pembroke House and Ealing, Registers of Admission, 1878. 
maintenance of each second-class patient (in addition to $£ 5$ p.a. for clothing). ${ }^{69}$ At that time most patients were between fifty and seventy years old, and the majority were classified as suffering from dementia (50 patients out of a total of 74). On 24 June 1892 the remaining 76 elderly patients were classified as follows: 5 chancery male patients, 18 first-class male patients, 40 lower-class male patients, 5 first-class female patients, and 8 second-class female patients.

The splendid Elm Grove Estate succumbed to profitable property speculation when the India Office sold it to Leopold de Rothschild. He demolished the building and had the land “developed" in 1894, contributing to London's burgeoning suburban sprawl. ${ }^{70}$

\section{The Patients: "Indian Insanes"}

With very few exceptions-and notwithstanding the fact that the inmates at Pembroke and Ealing were labelled "Indian Insanes"- the majority of patients were, of course, Europeans. Their symptoms and family histories were similar to those of patients in other private and public asylums in Britain, even though there were some exotic features in the way mental derangement presented itself to the doctors. For example, a former Lieutenant in the Indian Army had "imagined himself transformed into a vegetable, an artichoke, and was in the habit of taking advantage of every shower that fell in order that he might be properly watered". ${ }^{71}$ In the case of Private Peter N, the patient's mind was considered to have "gone" because of his habit of consuming large quantities of "Indian bhang" (hemp). Gunner Thomas $\mathrm{G}$ of the 2nd Troop Horse Artillery had first shown signs of strange behaviour on a march from Pune to Sind, when he absented himself from the troop and "took refuge in a Tree in the Forest". Private Joseph G, who was transferred from Trinidad, did not fit in well with military requirements when he refused to speak or perform military duties, disobeying and even insulting his superior officers. Private John M's mind became unhinged out of fear that he was suffering from venereal disease. Henry $\mathbf{H}$ of the First Fusiliers went mad after only one year's service in India following the "appalling cholera which carried off so many men of his Regiment", leaving him to fear that he should die. J $\mathrm{H} \mathrm{F}$, in contrast, was considered incurable, as he suffered from the somewhat more pleasant, but frequently challenged, idea that he was an emperor. Seaman William E continued to suffer from the religious hallucinations which he had previously nurtured at Bethlem Asylum, before slipping through the recruitment health check on embarkation to India. Despite his history, William was considered "apparently convalescent". His companion, Seaman William $\mathrm{H}$, by contrast, was more irritating in "repeating with the most painful perseverance" an idea then also common among the British ruling elite in India, "I am a heavenly God' or 'I am a white man'". Annoying though some patients' symptoms were to the asylum personnel, patience seems to have been easily shown to well-connected officers such as Peregrine $\mathrm{T}$ (who continually made his hatred of his father and mother, Colonel and Mrs T of Baker Street, known to everybody). It was reported that "the most certain method of gaining his confidence is by treating him with respect".

69 Ibid.

70 Ealing Public Libraries, Local CollectionElm Grove, see note 65 above.

71 For details of the "artichoke" case see Ernst and Kantowsky, op. cit., note 16 above. Information on all other cases are based, unless otherwise noted, on IOR: PELA, Medical Certificates, 1830-1889, Case Books, 1846-1892. 
The exotic title of 'Indian Insanes' on Pembroke's and Ealing's 'Book of Medical Certificates' might well raise the expectation that their patients suffered from culturally specific syndromes induced by the "heat and dust" of the East and exposure to a fascinating and complex culture which is, even today, said to instil a love-hate relationship in Europeans. Especially for romantic Victorians (and nomadic post-modernists)-some of whom were self-styled "pilgrims in search of the picturesque", 72 for whom the supposed mystique of the "Orient" had an appeal which challenged the western restraints of reason and trespassed on the boundaries of sanity-service in India could well be seen as a factor in mental confusion and derangement. Cases such as that of Gunner Francis $\mathrm{H}$, who fancied himself to be "Lord Byron", may indicate that at times the lure of the light of the Orient did indeed strangely affect certain Europeans in the East. ${ }^{73}$ However, despite the occasionally outlandish content of inmates' symptoms, the majority of patients admitted to the East India Company's asylums in Britain suffered from a range of problems which were unlikely to fascinate the romantically inclined: alcoholism, venereal disease, malnutrition, "zymotic disease", ${ }^{74}$ stress induced by military discipline, repeated infectious illnesses, nostalgia, boredom, "fevers", 75 grief, together with an inherited predisposition or constitutional weakness. ${ }^{76}$

Similarly, although since the Second World War and the Korean War military, naval and civilian duty in foreign countries has been acknowledged as particularly stressful for Caucasians, warranting psychological briefing and debriefing sessions built into employment contracts (if not psychological and psychiatric post-service treatment), during the East India Company's time not much consideration was given to these factors. ${ }^{77}$ The overwhelming majority of those seen to suffer from mental breakdown in India were returned to duty after a few days' rest at the local surgeon's hospital, having received no particular "psychological" or "psychiatric" treatment. Some of those who

72 F Parkes, Wanderings of a pilgrim in search of the picturesque, London, 1852.

73 For a case-study of "Lord Byron" see Ernst and Kantowsky, op. cit., note 16 above.

74 This term was used increasingly from the 1860 s onwards to refer to diseases caused by "zymosis" (a process by which specific poisons caused molecular changes in the blood). Diseases, like cholera, which were thought to emanate from decaying organic matter, were classified as "zymotic". M Pelling, Cholera, fever and English medicine 1825-1865, Oxford University Press, 1978, pp. 113-45.

75 See, on the nosology of fevers, W F Bynum, 'Cullen and the study of fevers in Britain, 17601820', in W F Bynum and V Nutton (eds), Theories of fever from antiquity to the Enlightenment, Medical History, Supplement No. 1, London, Wellcome Institute for the History of Medicine, 1981, pp. 135-47.

76 See M S Thompson, 'The wages of sin: the problem of alcoholism and general paralysis in nineteenth-century Edinburgh', in Bynum, Porter and Shepherd, op. cit., note 8 above, vol. 3, pp. 316-40. W F Bynum, 'Chronic alcoholism in the first half of the nineteenth century', Bull. Hist. Med., 1968, 17 (2): 160-85. See also, Curtin, op. cit., note 4 above.

77 See, for example, E Ginzberg, et al., The ineffective soldier: lessons for management and the nation, New York, Columbia University Press, 1959, 3 vols; for shell-shock and war neuroses/psychoses see H Merskey, 'Shell-shock', in Berrios and Freeman, op. cit., note 8 above, pp. 245-67; C Feudtner, "Minds the dead have ravished": shell shock, history, and the ecology of disease-systems', Hist. Sci., 1993, 31: 377-420. M Micale, 'Hysteria male/hysteria female: reflections on comparative gender construction in nineteenth-century France and Britain', in M Benjamin (ed.), Science and sensibility: gender and scientific enquiry, 1780-1945, Oxford, Blackwell, 1991, pp. 200-39. See also, on the decline of psychological interpretations of mental illness in the late nineteenth century, L S Jacyna, 'Somatic theories of mind and the interests of medicine in Britain, 1850-1879', Med. Hist., 1982, 26: 233-58; and M Clark, 'The rejection of psychological approaches to mental disorder in late nineteenth-century British psychiatry', in Scull, op. cit., note 8 above, pp. 271-332. 


\section{Asylum Provision and the East India Company}

ended up in Pembroke or Ealing would a century later have constituted only a small proportion of those categorized as suffering from stress and trauma related disorders. At the same time, the Company's insane could also be seen as that small fraction of people who were considered so profoundly deranged that they could no longer be handled within the expatriate community or within the confines of military institutions.

More importantly, the medical and managerial priorities which prevailed were very different from those following the First World War. Europeans in India during the first half of the nineteenth century were likely to die from some physical disease long before they had a chance to develop psychological symptoms. ${ }^{78}$ The state of health among the British in India improved considerably over the course of the nineteenth century. However, lowerclass personnel in particular were more likely to receive punishment or imprisonment for strange and unruly behaviour than be diagnosed as suffering from any mental problem or affliction. The "cat o' nine tails" and solitary confinement were then to the Company's soldiers and sailors what the couch, medication, and behaviour therapy became for US marines and Britain's "Falkland heroes".

The relative insignificance of mental illness in nineteenth-century British India is, of course, echoed in the statistical data. The European civilian and military population in India shortly after the Indian Rebellion (the "Mutiny"), in 1861, was calculated at 125,945 - of whom 84,083 were in military service. ${ }^{79}$ Yet the case-books of Pembroke House and the Royal India Asylum mention only 646 patients between 1818 and 1892 who were considered fit subjects for treatment at the Company's asylum in England. Most of these (about three-quarters) were, of course, admitted during the decades before Company rule was replaced by Crown rule in 1858. (Only 23 patients, mainly old, retired, and demented former Company officers, were admitted between 1881 and 1893.)

The asylum statistics also reflect to some extent the general demographic features among Company employees. The majority of patients in Pembroke House and the Royal India Asylum consisted of unmarried, young males who served in the Company's army and navy (74 per cent and 5 per cent respectively). 70 per cent of patients were single, and although those admitted after the Mutiny tended to be much older, most, namely 80 per cent, were under 40 years old. Although by 186115 per cent of the European population in British India consisted of women, only 8 per cent of all patients admitted to Pembroke House and the Royal India Asylum were female - a phenomenon that does not permit us to apply Showalter's thesis of madness as a "female malady" to British India. ${ }^{80}$

The country of birth of patients was not always known to the Company authorities, although recruitment officers and surgeons in India were repeatedly urged to trace patients' family histories with a view to contacting relatives and passing the cost of maintenance on to them. Patients did not always oblige by providing such information

78 See, for data on mortality rates, Royal committee on the sanitary state of the army in India, London, Eyre and Spottiswoode for HMSO, 1863. See also, Curtin, op. cit., note 4 above.

${ }^{79}$ Royal committee, op. cit., note 78 above, p. XXIV.

80 Unless otherwise noted, and like all statistical data referred to in this section, the data on gender are based on the statistics collated by the author from the original sources (IOR: PELA, op. cit., note 16 above). On gender and madness in England see E Showalter, The female malady: women, madness, and English culture, 1830-1980, New York, Pantheon Books, 1985. For a discussion of Showalter's thesis see W Ernst, 'European madness and gender in nineteenth-century British India', Soc. Hist. Med., 1996, 9: 357-82. 


\section{Waltraud Ernst}

(and where they did, relatives were, in any case, frequently unwilling or unable to afford the cost of institutional care). The majority of patients on whom information was available were of English or Irish extraction ( 44 per cent and 40 per cent respectively), with a minority from Scotland ( 9 per cent) and from the Continent ( 2 per cent), whilst 4 per cent of asylum inmates had been born to Europeans in India.

A relatively high percentage of the Company's military and naval servants sent to an asylum belonged to the junior and senior officer rank (16 per cent and 2 per cent respectively), with 77 per cent soldiers or sailors and 5 per cent non-commissioned officers. The question arises whether this fact substantiates the contemporary assumption about madness being more prevalent among the educated, higher classes. Dr J MacPherson, in charge of the Calcutta Lunatic Asylum in the 1850s, expressed this view when he pointed out in his Report on insanity among Europeans in India, that "the usual rule prevails - that the more educated classes are more prone to [attacks of insanity] than the less so". ${ }^{81}$ It is difficult to arrive at any firm conclusions on the basis of these data. However, within the context of the Company's colonial service it seems likely that unruly or odd and eccentric behaviour among the lower classes was frequently dealt with by martial law and disciplinary punishment, while among the higher classes it was interpreted as temporary mental aberration rather than wilful or intentional disregard of duty.

From the individual case reports sent from India with patients it is evident that a great number of them had suffered from a variety of physical ailments either before the appearance of mental symptoms or in addition to them. Asylum superintendents in England, however, did not appear to take much cognizance of these patients' medical-somatic prehistory. In only 25 per cent of cases was explicit reference to patients' previous somatic ailments made by the doctors attending lunatics in England. ${ }^{82}$ Most prominent among these were delirium tremens (16 per cent), sunstroke (15 per cent), general paralysis and partial paralysis (12 per cent), "fevers" (10 per cent), stomach and bowel diseases ( 9 per cent), injury through fall, blow or shooting ( 9 per cent), and epilepsy (8 per cent). Some of these categories (such as DTs, GPI, and epilepsy) were also reported in other private mad-houses in England. Others, like sunstroke, could, in the nineteenth century, be considered as more specific for an asylum receiving patients transferred from what were then referred to as the "tropics". However, these data are difficult to interpret given the low numbers involved, the widely varying presuppositions underlying diagnosis, and the absence of one common standard as to what were considered to be the relevant factors in a patient's case-history.

The "causes of death" which were attributed to patients are not beyond question eitherdespite the fact that those mentioned appear to be more or less congruent with what we know of factors involved in institutional mortality during the nineteenth century in general. About 40 per cent of patients who died in Pembroke House or the Royal India Asylum succumbed to a range of ailments connected with pneumonia, bronchitis and phthisis. ${ }^{83}$ Approximately 16 per cent died from general paralysis, and about 22 per cent from "decay" or old age.

$81 \mathrm{~J}$ MacPherson, Report on insanity among Europeans in Bengal, founded on the experience of the Calcutta Lunatic Asylum, 1854, review in Calcutta Review, June 1856, 26: 592-608, p. 603.

82 Reference to patients' medical-somatic prehistory was made in 163 out of 646 cases.

${ }^{83}$ On problems about nomenclature in regard to these conditions see L Bryder, "Not always one and the same thing": the registration of tuberculosis deaths in Britain, 1900-50', Soc. Hist. Med., 1996, 9: 253-65; Allan Mitchell, 'An inexact science: the statistics of tuberculosis in late nineteenth-century France', Soc. Hist. Med., 1990, 3: 387-403; F B Smith, The retreat of tuberculosis, 1850-1950, 
Intemperance was mentioned in 110 cases as a "supposed cause" of insanity, only exceeded by "exposure to unknown conditions" (115 cases). ${ }^{84}$ In the case of the latter category, it is unclear whether the diagnostician did not know what the conditions were, or whether he wished to imply that the patients had suffered from being exposed to conditions which were beyond the range of the familiar. Other causes such as "tropical climate, sunstroke" (52 cases), "hereditary, predisposition" (30 cases), "bodily disorder, metastasis, injuries to the head, general paralysis, epilepsy" and "sudden fright, anxiety, fall" (21 cases) are given too infrequently once patients arrived in England to permit further sensible statistical analysis. In general, it appears that although doctors in England insisted on the transmission of patients' medical histories from India, they scarcely referred to them in their own statements on patients' progress. It seems doubtful whether a patient's medical case-history in India impacted in any specific and weighty way on the treatment applied in Britain. An exception to this may have been the presence of scurvy and general or partial paralysis following patients' passage from India. Both of these factors tend to be commented on and responded to (with lime juice and good diet in the first case, and an additional attendant or servant to assist the patients in the second).

In contrast to other private mad-houses, most of Pembroke House's patients were admitted by authority of the East India Company (about 68 per cent) before 1858, and those in the Royal India Asylum by that of the Honourable Council of India ( 29 per cent) between 1858 and 1892 . Only 10 per cent of patients were referred by friends and relatives. This is, of course, explicable by the fact that prospective patients' symptoms usually developed while they were stationed in India working for one of the Company's various service branches, usually without a local network of family or friends to fall back on.

The question arises to what extent the patients passing through the Company's asylums should be considered representative of British madness in India, if not in a quantitative, at least in a qualitative sense. Pembroke House and, subsequently, the Royal India Asylum were, of course, intended to cater for insane former Company employees and their relatives only. However, there were other establishments which received Europeans returning in a state of mental derangement from service in India. Rich families preferred to send their relatives to exclusive first-class institutions such as Ticehurst, where patients were not accommodated alongside lunatics belonging to the lower social classes, as was the case in the Company's asylums. It is also difficult to establish how many lunatics were handed over to the care of friends and family, in India or on arrival in Britain. Further, a number of those sent home every season as time-expired men, or those of the higher classes seen to be in need of a refreshing furlough, though of sound mind at the time of their arrival in England, may at some later stage have suffered from mental problems which could be traced back to their time in India. The exact number of these, and therefore the extent to which Pembroke House and the Royal India Asylum could be seen to have catered for a representative number and a unique kind of patient returned from India, is difficult to ascertain.

London, Croom Helm,1988; S Szreter, 'The importance of social intervention in Britain's mortality decline, $c$. 1850-1914: a re-interpretation of the role of public health', Soc. Hist. Med., 1988, 1: 1-37, esp. pp. 11-13.

84 Reference to the supposed causes of insanity was made in a minority of cases. Sometimes a combination of suspected causes is given (e.g., intemperance, exposure and tropical climate); these do not always seem to be connected to the information on patients' medical-somatic prehistories. 


\section{The Treatment: "humane and enlightened"}

The records available on the treatment and management of the insane are, of course, in the main one-sided, as they were created by those in charge rather than by those on the receiving end of psychiatric and medical intervention. Nevertheless, it seems likely that conditions at both Pembroke House and the Royal India Asylum were comparatively congenial to inmates' health, and may, in the case of first-class patients, have reached, if not an idyllic, then at least an acceptable, standard within the context of the nineteenth century. Many abuses and bad conditions in private and public asylums had been revealed and investigated during the decades immediately preceding the opening of Pembroke House. No evidence exists that similar circumstances prevailed in the Company's establishments.

In fact, a close surveillance was kept for potential misdemeanours by asylum staff and negligence or profiteering on the part of the asylum superintendent. Like other private licensed mad-houses, Pembroke House and the Royal India Asylum were subject to regular inspection by the Lunacy Commissioners. ${ }^{85}$ As the Commissioners were on the whole not in favour of the private "mad-business", any untoward occurrences would have been seen as added leverage for nudging the Company into changing its private enterprise bias. As it happened, asylum superintendents kept all the required registers and case books meticulously, and on no occasion could the Commissioners during their periodic visitations report anything controversial.

In addition to the Commissioners' watchful and potentially disapproving eyes, the East India Company's own Examining Physician attended the institutions four times a year with a view to reporting back to the Company on whether standards were being kept up and whether the contract entered into by the Company continued to be advantageous. ${ }^{86}$ The Company's Court of Directors had a vested interest in steering clear of any hint of mismanagement or improper treatment of its mad employees. Its reputation was clearly at stake during a period when humanitarian reformers were beating the drum of lunatics' welfare, and were also inclined to be suspicious about a private Company's interest in and ability to maintain (costly) humane conditions within institutions. The Company's continued existence depended not least on its ability to show evidence of its enlightened and humane administration in India as well as in England, as its affairs were subjected to scrutiny by a parliamentary Board of Control and to extensive parliamentary investigation before the renewal of its royal charter every twenty years. Therefore any threatened changes for the worse in regard to Company lunatics' conditions were thwarted, as in 1870, when the superintendent at Pembroke House suggested that the inmates should be transferred to Camberwell, a large metropolitan licensed house which received mainly pauper lunatics and was able to offer accommodation and treatment at comparatively low rates. ${ }^{87}$ The Company's asylum was unique in the way in which it was monitored not merely by the Lunacy Commissioners but also by the Company's authorities, who had a

\footnotetext{
85 For Lunacy Commissioners see note 19 above.

86 For a discussion of the Commissioners' frequently lax and uncoordinated approach see Hervey, op. cit., note 19 above, esp. p 113.
}

\footnotetext{
87 The Visitors of Portsmouth and Southampton asylums had found that it was cheaper to send patients to Camberwell House than to a neighbouring county asylum. See Parry-Jones, op. cit., note 7 above, p. 59-60.
} 


\section{Asylum Provision and the East India Company}

vested interest in maintaining an acceptable standard of "humane and enlightened treatment", in accordance with the principles laid down by asylum reformers such as John Conolly and the Tukes. ${ }^{88}$

Even when compared with descriptions of the more exclusive private mad-houses, conditions at Pembroke and the Royal India Asylum came close to what asylum reformers could have hoped for in the nineteenth century. Patients of both the lower and the higher social classes received ample food, tobacco, wines and beers, and their physical condition was attended to by the usual means of regular bleeding, purgatives, and stimulants. ${ }^{89}$ They were also able to engage in occupations and amusements, although the former were mainly available to second-class inmates and the latter to those of the higher classes. The more basic activities, which included gardening, wood-chopping, bricklaying, housework, and brush and mat making, were considered valuable components of moral treatment and could be regarded as the precursor of occupational therapy. The higher orders of asylum society were, by contrast, offered diversions such as billiards, chess, music, dancing, skittles, walking beyond the grounds, as well as opportunities to watch or take part in dramatic performances, or to go riding. ${ }^{90}$ The scenery for such gentlemanly pursuits improved considerably when the patients were moved from Hackney to picturesque Elm Grove, Ealing. For those able to read, the railway editions of novels, as well as newspapers and magazines such as The Times, the Standard, the Illustrated News, Macmillan's and Cornhill Magazine were provided. During the later decades of its existence, the Company's asylum contained a majority of patients belonging to the "educated classes", who benefited from the literary and recreational pursuits on offer (although a great number of them were by then very old, and described as debilitated and, frequently, as paralysed). At times, patients' friends or relatives would even go to the expense of sending them to the sea-side for recreational and rejuvenating holidays. Overall, there is little evidence of the gloom and doom associated with some other private and public mad-houses. ${ }^{91}$

One important feature of any nineteenth-century asylum set on gaining a reputation for humane and enlightened treatment was the absence of mechanical restraint.This policy was adopted in Pembroke House well before the demand for the "total abolition of

88 On Conolly see, A Scull, 'A Victorian alienist: John Conolly, FRCP, DCL (1794-1866)', in Bynum, Porter, and Shepherd, op. cit., note 8 above, vol. 1, pp. 103-50; $M$ Fears, 'Therapeutic optimism and the treatment of the insane', in R Dingwall (ed.), Health care and health knowledge, London, Croom Helm, 1977, pp. 66-81; W F Bynum, 'Rationales for therapy in British psychiatry, 1780-1835', Med. Hist., 1974, 18:317-34; A Scull, C MacKenzie, N Hervey, Masters of Bedlam: the transformation of the mad-doctoring trade, Princeton University Press, 1996.

89 For example, during the quarter from October 1845 to January 1846 , the asylum superintendent charged the East India Company for the following expenses: $£ 55$ for medical attendance (of which approximately $£ 27$ for 22 "superior patients", and approximtely $£ 28$ for 56 "inferior patients"), $£ 15$ for wine or spirits (of which $£ 25 \mathrm{~s} 6 \mathrm{~d}$ for rum and water for a Mr M alone), $£ 17$ for ale or porter, $£ 24$ for tobacco. IOR: Letter from Messrs Williams \& Son, Bill for Maintenance of Patients at the Lunatic Asylum, 31.1.1846, Home Correspondence (Mil), 18-28.2.1846, 3888.

90 IOR: PELA, Miscellaneous correspondence and numerical returns of patients, 1857-65, 28-9.

91 Although data collated by asylum superintendents need to be evaluated with caution, those few statements by patients which remain in the case-books testify to conditions which were positively appreciated by inmates, and to the trust and gratitude bestowed on the superintendent. See, for an example, the case of Lieutenant B, who wrote a pleasant letter to Dr Williams, thanking him and "expressing himself very happy and comfortable". Ernst, op. cit., note 16 above, p. 221. 


\section{Waltraud Ernst}

restraint" was at its height in the late 1830 s and early 1840 s. A non-restraint policy was still pursued in the Royal India Asylum towards the end of the nineteenth century. In other institutions the practicability of this principle had proved difficult, if not doubtful, in the face of the violence of patients' symptoms during an age without tranquillisers and medical straitjackets. ${ }^{92}$ Admittedly, the majority of patients at the Royal India Asylum in the later decades suffered from various forms of debility rather than excitement and violence, so that non-restraint became more feasible. It must have been difficult to pursue this regime during the early part of the century, when Pembroke House received a considerable number of very young lower-class patients exhibiting violent symptoms who-unlike first-class inmates-would not usually be entitled to the care and vigilance of personal servants and attendants.

It is not surprising that at times patients managed to escape (much to the displeasure of the Company), as in May 1865, when the India Office insisted that "greater vigilance is necessary on the part of the attendants and keepers, to prevent men from escaping from Pembroke House without detection". ${ }^{93}$ Escaping lunatics displeased the India Office and possibly added to the nightmares of Hackney residents, but, from the perspective of asylum inmates and humanitarian reformers alike, this may have been a small price to pay for the inmates' freedom from being handcuffed to the wall or strapped to the bed.

Patients' treatment in the Company's asylums was thus very similar to that in the more renowned, and more "humane", institutions in Britain. It is true that criticisms were raised by the Commissioners in Lunacy, for whom the private institution was a thorn in the flesh; by the Hackney Union and the Unions of towns close to the sea-ports where Company servants were disembarked, as they preferred pauper lunatics to be confined in the Company's rather than local council asylums; and by the India Office concerned about escaped inmates. Significantly (apart from the problem of escapees) these criticisms arose from general concerns about the private care arrangements of the Company and the complications of revised legal provisions, rather than about conditions within the asylum itself.

That the Company asylums should compare favourably with the better mad-houses then existing in England is even more noteworthy if it is considered that the sort of institutions Pembroke House and the Royal India Asylum might more reasonably be compared with are other military and naval establishments such as the Naval Hospital at Haslar (in which some accommodation was set aside in $\mathbf{1 8 1 8}$ for insane officers and seamen) and Fort Clarence, Chatham (opened in 1819 as a military asylum). Even though the East India Company more often secured for its servants in India an early grave than a large fortune, it did provide on a better scale for those who managed to return to its mad-houses in England.

However, towards the end of the nineteenth century, the Company's asylums shared one less positive feature with other such establishments in England, namely that of becoming receptacles for the "chronically insane". The majority of the inmates remaining at the

92 On evidence that even at the Retreat at York restraint had been used see Digby, 'Moral treatment', op. cit., note 63 above. See also, $N$ Tomes, 'The great restraint controversy: a comparative perspective on Anglo-American psychiatry in the nineteenth century', in Bynum, Porter, and Shepherd, op. cit., note 8 above, vol. 3, pp. 190-225; A Suzuki, 'The politics and ideology of non-restraint: the case of the Hanwell Asylum', Med. Hist., 1995, 39: 1-17.

93 IOR: PELA, Letter by India Office to

Pembroke House, 29.5.1865, Medical Certificates, $1865-6$. 


\section{Asylum Provision and the East India Company}

Royal India Asylum on its abolition in $\mathbf{1 8 9 2}$ had by then been confined for many years. Once no more new admissions were received, these patients had, necessarily, predominated in asylum statistics. The tendency for patients' length of stay to increase over the decades was not a reflection of bad management and treatment, or of a wish to keep social undesirables locked up out of sight, but of the mere fact that "incurable" cases (mainly the paralysed and debilitated) tended to accumulate over time.

It is, of course, generally difficult to establish whether institutional discharge rates during the nineteenth century did indeed reflect the number of those who had "recovered", "improved", or been "cured". The validity and reliability of these categories for diagnostic and predictive purposes remain highly controversial. Nevertheless, it appears that the rate of "turn-over" of patients in the Company's asylum during the early and middle decades of the nineteenth century was very much in line with what was then common at other asylums in England. The Company's asylum was not a place which would easily fit in with gloomily gothic stereotypes of lunatics being locked up, confined out of sight and forgotten by the world. It was not only finances which played a role here. Early nineteenth-century medical doctrine, which asserted that madness was in many cases curable, impelled staff to discharge patients when symptoms subsided. Further, neither the asylum proprietor (who made a living from the rates charged for patients) nor the Company were interested in keeping people in institutions for longer than absolutely necessary. The owner was keen to preserve his reputation, and high cure-rates were a feature well worth advertising in the face of fierce competition in the mad-house trade. The Company, for its part, was eager to limit the cost of institutional treatment and to avoid allegations of improper or illegal confinement of former employees.

It may be asked whether any special treatment was applied at Pembroke House or at the Royal India Asylum. After all, the inmates shared a specific and unique set of previous experiences which may have had a bearing on the nature and expression of their mental affliction, and thus have made treatment specifically adapted to "Indian Insanes" necessary. As has already been argued, this question, however appropriate in regard to present-day psychiatric doctrines about the role of civilian and military service in unfamiliar cultural and environmental surroundings, was not then one of the concerns of the psychiatric profession. Although at the time people with a temporary expatriate experience in the East were generally considered by their compatriots in Britain to have acquired idiosyncratic if not eccentric ways, this conviction was not reflected in any specialized diagnostic or therapeutic regime. The diagnosis and therapy of returned Company servants followed the practices then commonly applied to any other insane person. Admittedly speculations about the effect of the sun, the climate, the unknown conditions of the East and so on were legion. But they appear not to have had much of a practical impact on clinical procedures-apart from basic interventions such as the prescription of phlogistic and anti-phlogistic remedies when people changed climatic zones. $^{94}$

People were mostly perceived to suffer from temporary insanity (expressed in mania, melancholia, idiocy and dementia) rather than from the effects of ex oriente lux, even though

\footnotetext{
94 For a discussion of phlogistic and antiphlogistic therapies see S B Thielman, 'Madness and medicine: trends in American medical
}

therapeutics for insanity, 1820-1860', Bull. Hist. Med., 1987, 61: 25-46, pp. 33-8. See also, Bynum, op. cit., note 88 above. 


\section{Waltraud Ernst}

some doctors were intrigued by their patients' often colourful experience of heat and dust, adventure, and alien spectacles, and frequently devoted a lot of space in the case reports to picturesque narrations of compelling and bewildering details of patients' histories.

\section{Conclusion}

The development of colonial psychiatry can be understood only as an integral part of the politics of empire. Institutions for former colonial servants in Britain also need to be assessed within the wider context of prevailing political and administrative priorities. ${ }^{95}$ The Company's Court of Directors played, in the first place, a vital role in the establishment of reformed, humane and efficient asylums; and, only secondarily, in the provision of a medically informed treatment regime. The Court was heir to and representative of a tradition of private enterprise and well-structured military administration. Both these influences made themselves felt in the organizational set-up and in the internal management of the Company's psychiatric institutions. However, the Company had another, perhaps even more compelling, reason for keeping its mad-houses in good order. It was subject to scrutiny by the British government through a Board of Control and parliamentary investigations on the occasion of the periodic renewal of its charter. It was therefore highly motivated to exert stringent control to ensure the efficient and reformed management of its institutions.

Consequently the institutions' medical superintendents were subject to control by various agencies: the Company's physician who reported back to the Court of Directors; the government's Board of Control which in turn scrutinized the Court's correspondence and reports; and, finally, the Lunacy Commissioners. Although the importance of medical treatment was emphasized, a sense of military and bureaucratic order and efficiency was very evident, and may have suited not only the Company and the Lunacy Commissioners but also the asylums' mainly military clientele. The major model for the Company's asylums, in India as well as in Britain, was the Hanwell Asylum which advertised itself as a rationalized institution based on a reformed non-restraint regime. ${ }^{96}$ From its inception in 1818 the dogma of non-restraint was practised at Pembroke House, and persisted until 1892 when the Royal India Asylum was demolished. Following the transfer of the colonial administration of India from the Company to the British government in 1858 and, subsequently, the disbandment of the Company's army and navy, few new patients were admitted to the Company's asylum in England. Those who remained were considered chronically insane, requiring mainly intensive nursing care. This made any physical restraint unnecessary and, together with institutional order and cleanliness, led to an emphasis on the diligence and nursing skills of patients' personal attendants rather than on the medical officer's expertise in psychological medicine.

95 For a similar argument on Poor Law policies see P Bartlett, 'The Poor Law of lunacy: the administration of pauper lunatics in mid-nineteenthcentury England with special emphasis on Leicestershire and Rutland', University of London, PhD thesis, 1993; Suzuki, op. cit., note 92 above; and B Forsythe, J Melling, and R Adair, 'The New Poor Law and the County Pauper Lunatic Asylum- the Devon experience 1834-1884', Soc. Hist. Med., 1996, 9: 335-55. See also, J K Walton, 'Casting out and bringing back in Victorian England: pauper lunatics, 1840-70', in Bynum, Porter, and Shepherd, op. cit., vol. 2, note 8 above, pp. 132-46.

96 For a discussion of Hanwell Asylum see Suzuki, op. cit., note 92 above. 


\section{Asylum Provision and the East India Company}

The composition and characteristics of the asylum population changed considerably between 1818 and 1892, from a majority of young, male military servants, displaying symptoms of mania, who were discharged after a short period of standard medical treatment, to a steady mass of aged, paralytic and debilitated patients requiring long-term nursing care. ${ }^{97}$ At other institutions in Britain, the composition of the asylum population tells us about the response of patients' families to insanity, mirroring their economic and emotional capabilities to cope with lunatics at home, ${ }^{98}$ and about the preferences and policies of local Poor Law officials. ${ }^{99}$ In contrast, the admission procedures and the changes in the Company's asylum population mirror the behavioural and medical consequences of the military requirements and ideological preconceptions of colonial rule, as well as the changing nature of the politics of empire and of the Company's position within these.

\section{APPENDIX \\ The Source Material: The Records of Pembroke House and Ealing Lunatic Asylum ( India Office Records, London)}

A wealth of data has been preserved on the East India Company's semi-independent institutions. The records of Pembroke House and the Royal India Lunatic Asylum span the period from 1818 to 1892, and consist of 66 volumes which take up about eight feet of shelving space in the India Office Library and Records, London. The records have been catalogued by Anthony Farrington and provide a unique collection on the history of psychiatric treatment in the nineteenth century. ${ }^{100}$ Unlike records of other psychiatric institutions which are often dispersed among various locations, the Pembroke House and Royal India Asylum data have survived almost intact, and range from institutional and statistical to treatment data. This central availability of records is, of course, due to the way in which the private mad-house owners were accountable not only to the Commissioners in Lunacy but also to the Company's Court of Directors, whose administration was in turn scrutinized by a governmental Board of Control. The necessity of providing comprehensive data which documented every possible aspect of asylum affairs for various authorities' scrutiny has provided a mine of information for the medical historian.

The Case Books (which had to be kept from 1846 onwards in every asylum) contain valuable information for nearly every patient on biographical details, external appearance, symptoms, previous history, and regular statements on any changes in mental and bodily health. The Case Books of Pembroke House and the Royal India Asylum are among the few easily accessible private asylum case books.

97 These characteristics differ from those highlighted by MacKenzie with regard to Ticehurst, op. cit., note 53 above, esp. p. 147, and by $\mathrm{N}$ Tomes, 'The Anglo-American asylum in historical perspective', in C J Smith and J A Giggs (eds), Location and stigma: contemporary perspectives on mental health and mental health care, Boston, Unwin Hyman, 1988, pp. 3-20, p. 15. (Unfortunately Tomes provides no details on the sources or area of reference for her assertion that "19th-century asylums had fewer aged insane patients than existed in the population as a whole".)
98 Tomes, ibid., esp. p. 14, where she refers to studies by $\mathrm{N}$ Tomes, A generous confidence: Thomas Story Kirkbride and the art of asylum-keeping, Cambridge University Press, 1984; Walton, op. cit., note 95 above; and MacKenzie, op. cit., note 53 above.

99 Forsythe, Melling, and Adair, op. cit., note 95 above.

100 A Farrington, Guide to the records of East India College, Haileybury, and other institutions, London, HMSO, 1976. 


\section{Waltraud Ernst}

In addition, the holding comprises Medical Certificates (which had to be provided for every patient under the Act for the Treatment of Insane Persons, 9 Geo. IV c. 41 (1828)). Some of these are attached to voluminous statements of patients' histories, and thus constitute, together with the Case Books, an invaluable source for case studies. Registers of Admissions and Registers of Discharges, Removals and Deaths (kept under the Act for the Regulation of the Care and Treatment of Lunatics, 8 \& 9 Vic. c. 100 (1845)) occasionally provide, in addition to basic statistical material, copies of correspondence entered into by various authorities and relatives regarding individual patients.

The series of Medical Visitation Books and Journals (kept under the Lunatics' Care and Treatment Amendment Act, 16 \& 17 Vic. c. 96 (1853)) provide data on patients' illnesses while in the hospital, on the medical treatment applied in response to these, as well as records of doctors' visits and any injuries or deaths. This series, despite its potential for the investigation of clinical procedures and practices, is less accessible to the non-clinical medical historian than the other material, as it abounds in superb examples of doctors' legendary "bad" hand-writing and abbreviations unintelligible to the clinically uninitiated.

By contrast, the Visitors' and Patients' Books constitute a straightforward record of observations made by the Commissioners in Lunacy - relating both to the institution as a whole and to individual patients. However, the available records cover only a short period (1871-1891). Similarly, records such as the Register of Mechanical Restraint and the Day Books, Ledgers, Cash and Petty Cash Books relate only to the last two decades of the Royal India Asylum. Last but not least, even records of the Miscellaneous Correspondence and Numerical Returns of Patients, as well as documents relating to the Transfer of Patients in 1892, are available.

The above records constitute good source material for historians with an interest in patients' individual cases, official observations and administrative and clinical procedures. Similarly, a wealth of material is available for those who are mainly interested in institutional aspects. However, background knowledge of colonial history and of the nature and development of the East India Company as well as of British administration and European social life in the various provinces of British India is necessary in order to assess appropriately the relevance and meaning of administrative measures and of patients' stories. References alluded to in the records of Pembroke House and the Royal India Asylum can usually be traced right back to the various provinces in British India.

The records span nearly the whole of the nineteenth century from Company to India Office and Crown Rule. They thus provide evidence not only of changes in medical priorities but also in colonial administration, from sporadic and locally specific, to more uniform, centralized bureaucratic policies. 